\title{
Provision of Information Services to the Visually Impaired Students at Thika School for the Blind
}

\author{
Esther Njambi Mbugua \\ Department of Library, Records Management and Information studies \\ School of Information Sciences \\ Moi University, Eldoret \\ Kenya \\ Prof. Cephas Odini, PhD \\ Department of Library, Records Management and Information Studies \\ School of Information Science \\ Moi University, Eldoret \\ Kenya \\ Dr. Andrew Chege \\ Department of Library,Records Management and Information studies \\ School of Information Science \\ Moi University, Eldoret \\ Kenya
}

\begin{abstract}
Provision of information services is central to learning and instructional process in schools including those of the visually impaired students. However, in most cases subject materials and learning activities are designed with normal sighted in mind. Whilst educators have vastly improved teaching techniques and facilities, it is still a problem that visually impaired students experience difficulties accessing the ordinary curriculum and has been worsened by the use of technology. The study was informed by the Moore's Model of Social Needs and Wilson's Model of Information Behaviour. The study was conducted using a case research and maily used qualitatively and quantitatively approaches. Data was collected using interview schedules, the focus group guide and documentary review. The study establishes that provision of information to visually impaired students require improvement. The study concluded that authority and information providers in this area take recognition of visually information needs and channels of accessing information. The study's recommends improvement of the existing information services, system and channel of disseminating information to visually impaired to serve them without discrimination.
\end{abstract}

Keyword: visual impaired, information, provision, students, Kenya.

\subsection{Introduction}

The ability to access and use information on any subject gives an individual the opportunity to choose a path from many alternatives instead of being limited to a few perhaps unwanted or unfeasible choices (Fullmer \& Majumder, 1991). Nevertheless, little is known about the broad spectrum of information needs for everyday life of people with disabilities. Roth (1991) states that the information needs of individuals with disabilities are likely to include, but not be limited to service information, the nature of handicapping conditions, environmental accessibility, civil rights, financial assistance and advice, research and statistics, and service delivery models.

Individuals use all sensory organs to acquire information however, the sense of sight is most important.It has been estimated that human beings absorb as much as 80 per cent of information about their immediate environment by means of sight (Willetts, 1997). The visually impaired are thus, at greatest risk of being socially excluded as a result of limited access to information which has substantial long-term effects on a person's ability to carry out usual activities (Raymond, 2003). 


\subsection{Background to the Study}

Information is recognized as a vital commodity. It is undoubtedly and increasingly being recognized as a vital resource. Crawford (1978) was right when he described information as the fifth basic need of human beings ranking after air, water, food and shelter. The importance of information sought varies from person and discipline. Therefore information seeking behaviour depends upon a person's level of education, age, subject background and nature of their job, urgency of information and availability of sources (Singh, 2009).

\section{Visually Impaired Students in Kenya}

In the Kamunge Report (1988), the Government of Kenya (GOK) recognize the equal existence of persons with disabilities among its citizenry. The Koech report (1999) gives attention to this by highlighting special education needs.The GOK has not established any National Library for the blind. However, a Braille and Large Print Section which was established in 2000 at Kenya National Library Services (KNLS) are found only at the library's headquarters in Nairobi, no daily newspapers published in Kenya can be read by the visually impaired. Some of the institutions established to aid the physically challenged operate independently and also book production institution each operate independently (Person with Disability Bill, 2002).

According to Ochoggia (2003), library and information services for the visually handicapped students in Kenyatta University, a public university has largest number of visually impaired students, inadequate materials and staff lack the necessary skills to serve the visually impaired students. Muya (1990) asserts that the current state of library and information services for visually handicapped in Kenya is a sad story to tell due to lack of adequate funding.

\section{Categories of Visually Impaired in Kenya}

Heiman (2004) in International Journal of Special Education records that in Kenya, the Low Vision Project, groups students with visual impairments into five categories. The first four of these are based on the working definition of the World Health Organization based on the need to create a category for children attending special schools and programs for children who do not have a severe visual and do not require special education as long as their sight is constant (Verweyen, 2004).

\section{Information Providers}

Information professional have a moral obligation to make information available to all categories of users.(Winnie, 1994). Among this disadvantaged group are the visually impaired. Inaccessible information is a major barrier facing blind and partially sighted people. According to the World Health Organization (WHO, 2009) statistics, there are about 314 million visually impaired people globally with 45 million totally blind. Of these, $87 \%$ live in developing countries. Although visually impaired people cannot read the conventional print, they have the right to access information. That is, the right to read information in formats that are accessible to them. Friend (2009) stated that less than $5 \%$ of the information materials available to sighted library users are accessible to the visually impaired.

\section{Challenges in providing information services to the visually impaired}

The visually disadvantaged are likely not to participate as actively as they should in the development of a Community, owing this largely to their limited access to information. The products which could guarantee their access are scarcely available and very specialized. This is a contrast to the availability of a wide range of systems developed for the sighted population. The information needs of individuals with disabilities are likely to include, but not limited to service information, the nature of handicapping conditions, environmental accessibility, civil rights, financial assistance and advice, research and statistics, and service delivery models. "Recreation", includes listening to talking books supplied by organizations for the blind and sight impaired, is very important. There is need to provide appropriate information facilities, materials, equipment and a cadre of trained teachers, professional and support staff to address their needs at all levels. Therefore the situation draws the researcher to carry out a study that investigates the provision of information to the visually impaired with an aim of providing solution to access information. This is likely to achieve a state of equal opportunity for the visually disabled in accessing information as inferred by the Kenya Vision 2030, thus producing an informed society without partiality.

\subsection{Statement of the problem}


In the Kenyan educational institutions every student has the right to access libraries, to attend lectures and to participate in class activities as part of their basic right. However, in most cases, subject materials and learning activities are designed with normal-sighted people in mind. Whilst educators have vastly improved teaching techniques and facilities, it is still a problem that visually impaired students experience difficulties accessing the ordinary curriculum.

A visually impaired individual, who cannot read Braille, usually has access to print material by traditionally using a mediator like, a family member, a friend, a designated helper, or an organization. Apart from assisted access to print material, the visually impaired have employed the use of radio, audio cassettes and telephones to gain access to information. Braille is only used among those who have been blind from a young age, nonetheless, a large proportion of the visually impaired lost their sight ability at a later stage in life, thus, their inability to use Braille as a means to access information and as a common form of communication (Williamson, et al, 2000). There are a very limited number of items and formats which are accessible for use by the visually impaired. It is not a guarantee that the available converters such as scanners, reading machines, embossers and tape recorders, convert text to be permanently recorded in the desired format (Gallimore, 1999; Long, 1993; Porter, 1997). They occasional lack skilled and qualified staff members who would recognize the implications of visual impairment and the complexity of its impact. (Long, 1993).

Libraries have low levels of understanding information needs and the information seeking behaviours of visually impaired, illegible print formats, lack of assistive technology equipment and very minimal assistance in using audio devices. The challenge of providing equitable library and information services to the visually impaired requires the cooperation of all stakeholders. Williamson, Schauder and Bow (2000) state that people who are blind and sight impaired deserve to be provided with a range of ways of meeting information needs, as are available for people with normal sight so as to equitably participate in the information economy.

\subsection{Aim of the Study}

The aim of the study was to investigate the provision of information services to the visually impaired students at Thika School for the Blind, and to propose strategies for improvement.

\subsection{Objectives of the Study}

The objectives of the study were to:

i. Establish information needs for the visually impaired students

ii. Identify information sources that the students consult when seeking information

iii. Determine the types of special skills required to access information

iv. Identify different activities undertaken by visually impaired students while seeking for information.

v. Establish challenges faced by visually impaired persons while seeking information.

vi. Propose strategies to improve information access by the visually handicapped.

\subsection{Research Questions}

To achieve the stated objectives, the following research questions were addressed:

i. What are the information needs of the visually impaired students in Thika School for the Blind?

ii. What information sources do they consult when seeking information?

iii. Which type of special learning skills do they require to access information?

iv. How does the visually impaired student access need information?

v. What are the challenges faced by visually impaired persons while seeking information?

vi. What strategies are required to improve information access by visually handicapped students at Thika School for the blind?

\subsection{Assumption of the study}

1. The provision and access of information to visually impaired student in special schools in Kenya have been neglected.

2. Empirical findings of the study will help to enhance the provision of information to visually impaired student.

\subsection{Significance of the Study}


The study constitutes an addition to the existing body of knowledge on provision of information services to the visually impaired student. It will act as guide for policy formulation in provision of information and help to sensitize the government and other policy makers to establish information system that can address the issues of information provision of the visually challenged students. Finally practical solution to the challenges of services and use of information by visually impaired students in special schools in Kenya.

\subsection{Literature Review}

This chapter reviews related literature and provides a broader picture of information provision with emphasis on visually impaired people.

\subsection{Needs of visually impaired students}

Visually impaired students are investigated in assessment needs of vision status, nature and extent of the student's ability to use computers and other assistive technology to anticipate in the general curriculum. (Verweyen, 2004). They require skills to use of cassette recordings; recordings utilize compressed speech, personal computers, and optical scanners with speech output (Sorenson, 1999).

Orientation and mobility create an awareness of the environment in which they live and learn through trained and knowledgeable personnel. Educational instruction and learning needs is crucial in determining degree of vision loss of a visually impaired student the medium of reading and writing. Students who are blind and others have light perception will only use the tactile mode as their medium of reading and writing using Braille and they require communication devices such as slate and stylus, tape recorder, typewriters and computers. (UNESCO, 1995)

\subsection{Information source}

Singh (2009) asserts that information sources differ from user to user according to their convenience and availability of information sources. They are classified into Print and Non-print formats. Large print materials are very useful to partially sighted people which is both fiction and non-fiction titles (Deaton, 1993). Non-print materials are also used by the visually impaired persons, they includes; Audio visual, Cassettes and tapes recorders, Talking books, Internet, Telephone, Broadcast media and personal contact among others.

\subsection{Special learning skills for the visually impaired}

Skills required by visually impaired learners include: mobility skills, reading embossed writings, tough typing, sighted guiding and computer skills. Assistive devices required includes: Optical low vision devices which in most cases are used to provide some form of magnification (Klemz, 1977). Walsh, (2006) states Other daily equipment include writing aids, talking watches/ clocks, medicines dispensers, rain alerts, tactile and tape/compact disc player control (http//wwww.chrishigh.com/visual-imp.htm, accessed on July, 2012).

\subsection{Activities undertaken by visually impaired students include:}

The impaired students carry out experiments in science subjects such as Physical Science, Chemical Science and biological science, laboratory experiments and demonstration and Math activities.Kumar (2003) asserts that visually impaired people sit for the same exam as the sighted people but for them they are not given drawings and maps interpretation. Instead, they are given extra questions to cover for that section. Their exams are transcribed to Braille for them to do but again translated back to normal writing, mixed with other copies and marked without bias Physical education, fitness, and exercise are important to the well-being of people with visual impairments (Curry and Hatlen, 1987). Fullers and Majumber (1991) notes that blind and partially sighted people participate in outdoor sports and those with residing sight can continue to make use of their sight constructively and those totally blind can perform useful activities around the house and garden such as cooking and cleaning (Pinion, 1990).

\subsection{Challenges faced by visually impaired students while seeking information}

The visually impaired students face several challenges that make them prone to powerlessness and inability to participate in decision making and development programmes that affect them and their fundamental rights. They includes, Inadequatefinances, Inadequate collection,Inadequate Human Resources,Lackof Proper Technology, Difficulty in navigating environment,Social isolation,Access to documents,Professionalism,Copyright Act and National Information Policies 


\subsection{Research Methodology}

The study adopted case study design. The research approach used was qualitative with some aspect of quantitative research technique in the design of data collection instruments. The study population at the time of study was 720 . The study targeted a sample size of 97 respondents for study,calculate using Yamane (1967) formula. The study employed probability sampling by stratifying random for students and non-probability sampling purposive methods was used to select the key informants. Data was collected using interviews, focus group and documentary reviews. It applied interview schedule, focus group guide and documentation review. The data collected was organized and analysed thematically.

\subsection{Discussion of the Findings}

Discussions are represented by research questions

Table 1: Distribution of respondents by categories and students $(\mathbf{N}=97)$

\begin{tabular}{|l|l|l|l|l|}
\hline Categories & Class/key informant & Targeted population & Actual No interviewed & \% \\
\hline Totally blind students & Form 1 & 11 & 9 & 81.8 \\
\hline & Form 2 & 11 & 8 & 72.7 \\
\hline & Form 3 & 11 & 6 & 54.5 \\
\hline & Form 4 & 11 & 7 & 63.6 \\
\hline & Total & $\mathbf{4 4}$ & $\mathbf{3 0}$ & $\mathbf{6 8 . 2}$ \\
\hline Partially blind Students & Form 1 & 11 & 8 & 72.7 \\
\hline & Form 2 & 11 & 9 & 81.8 \\
\hline & Form 3 & 11 & 8 & 72.7 \\
\hline & Form 4 & $\mathbf{4 4}$ & 9 & 81.8 \\
\hline & Total & $\mathbf{8 8}$ & $\mathbf{3 4}$ & $\mathbf{7 7 . 2}$ \\
\hline Total Response & & $\mathbf{6 4}$ & $\mathbf{7 4 . 2}$ \\
\hline & & & & \\
\hline Quantitative sample size & $\mathbf{6 4}$ & 2 & $\mathbf{1}$ & 100 \\
\hline Key informants & Humanity teachers & 2 & $\mathbf{2}$ & 100 \\
\hline & Social science & 1 & $\mathbf{2}$ & 100 \\
\hline & Academic affairs & $\mathbf{1}$ & 100 \\
\hline & Librarian & 2 & $\mathbf{1}$ & 50 \\
\hline & Physical science & $\mathbf{2}$ & $\mathbf{8 8 . 9 \%}$ \\
\hline $\begin{array}{l}\text { Interview conducted } \\
\text { (qualitative sample size) }\end{array}$ & & $\mathbf{9}$ & & \\
\hline Overall response & & & $\mathbf{7 1 . 5 5}$ & \\
\hline
\end{tabular}

Combining the response rate of both qualitative and quantitative data collection gives a total response rate of $81.55 \%$. This is a fairly high response rate that is adequate for a research of this magnitude to proceed to analysis stage.

\subsection{What are the Information needs of the visually impaired student?}

The study showed that priority is given to evaluation need, how to use Braille, assistive devices, orientations and mobility needs.

\subsection{Information sources and support equipment}

Information materials available are print non print which was outdated, not currents and were inadequate to cater for all students. Braille books were in bulk and they cannot get the complete copy which was difficult to find the next set whereby Sometimes they move the next class without having some part of Braille which has hampered their studies as it was confirmed by the key informants, they stated that the little grants they receive from the government and well wishers is not adequate to purchase enough books for all students. 


\subsubsection{Support equipment}

The study also established that the students have support equipment such as Braille machines, few magnifying glasses and tactile. The Braille machines are however inadequate, broken and contain only a few diagrams for tactile. Worse still, the school has inadequate reading equipment such as embossed Braille machine, Computers, tape recorder, magnifier and sensory aids. One Television and a Radio are inadequate for the whole school.

\subsection{Types of special learning skills}

The study revealed that the special skills of the students such as mobility 53 (83\%), reading embossed writings of Braille 50 (78\%), sighted guiding 50 (78\%) were carried out immediately one reports to school.

However, they were not trained on how to use Vision Aids devices, Sensory Aids and the Internet. The key in formants stated that slow paced learners are sent to Machakos School for the blind for further training on the lacking skills to help them become more efficient.

\section{Library Services}

The study established that $55(86 \%)$ of the respondents stated that they usually access borrowing services, 47 (73\%), they are assisted in reading by sighted students, $44(69 \%)$ went through library orientation. Most of the reference materials are in print form, they do not have motivational programmes, discussions and club activities. The key informants stated that they have never organised other services for the students.

\subsection{Activities Undertaken by the Visually Impaired Students}

The study established that all students attend classes, do class work, read, perform class projects, do tests and examinations. However only $34(53.1 \%)$ specifically the partially blind do laboratory experiments and field work. The totally blind student which consisted of 30 respondents $(46.9 \%)$ stated that they do not do laboratory experiments and field work because they are not able to manipulate the specimens, chemicals and apparatus since they are dangerous to be handled without sight. Field work requires observations which are done through sight and therefore do not participate; this was further emphasized by the key informants that mixing of chemicals by the totally blind is hazardous to them.

\subsubsection{Co-curriculum activities}

The findings showed that the students do not participate much in outdoor games except athletics. The students' population that participates in athletics is relatively high at $44(69 \%)$. The high participation in athletics according to the students respondent were because they have an adapted field and efficient trainers, this was also emphasized by the key informants. A low participation in playing cards, drought chess, table tennis, cricket and golf as explained by the students and key informant is because the equipment required for these activities are not modified and playing cards and drought chess had residue sight.

\subsection{Challenges in accessing and using library resources}

The challenges that the students face according to the study were:

- Absence of library orientation programs

- Insufficient library materials

- Inadequate reading equipment

- Lack of technology

- T Inadequate Personnel

- Inadequate library space

\subsection{Proposed strategies to improve provision of information services to visually impaired}

Some of the proposed strategies recommended by the students are discussed hereafter.

\section{Proper library orientation}

The respondents proposed for prompt and proper planning of library orientation soon after they gain enrolment in the school to enable them access information independently and familiarize themselves with library layout and procedures, the hours of library operation and type of resources, its importance and benefit to enable them access and utilize the resources effectively. 


\section{Increase information materials}

A proposal was made to the Government of Kenya (GOK) to reduce the cost of materials for the disadvantaged groups like the visually impaired persons so that more books are procured. Donations from donors and wellwishers and requests be made to book publishers to provide Braille books in electronic format.

\section{Alternative reading equipment}

Considering the high cost of these materials, it was suggested that the school proposes to the GOK to automate their information resources for easier access.

\section{Information communication Technology}

There was a suggestion that the computer lessons be introduced at primary and secondary as mandatory in all schools. Free Internet facilities be installed and accessed at minimal or no cost and their computers equipped with assertive technology.

\section{Increase human resource capacity}

They suggested teachers can be approached for internship programs and the retired can volunteer their services to disadvantaged groups.

\section{Expansion of library}

The students acknowledged the significance of the Library to them despite its small size. They suggested that the computer room which is currently empty be stocked with reading materials for one \& two students. The main library is left with reading materials for third and fourth form students. Outdated materials can be weeded to create more space. The walking space need to be made wide for easy mobility which can be achieved by the school seeking support of resources from religious organization and private organization.

\subsection{Recommendations}

The study recommends the following to improve the provision of information services to the visually impaired students.

Diversity of activities that can be undertaken by visually impaired student at Thika School for the blind The study recommends that the school adds three dimensional models; apparatus to be modified, electronic light probe to be used for exploring parts inaccessible to fingers, skeleton, pictures which shall be useful to the totally blind students. Adaption of physical education and sports should be considered as part of their co-curricular for their well being. Indoor games and outdoor games should be introduced to them (Bruce, 2001). Field ground need to be modified to nurture their talents and reduce monotony from normal curriculum.

\section{Additional reading equipment for visually impaired students}

The school need additional assertive devices including personal computers with speech output to access to information. communication devices can be used for taking notes, when braillers are not available. Tape recorders for students to record lectures, discussion and do their assignments. Computers can be used for voice synthesizers.

\section{Broadening of information services}

The study recommends the introduction of other library services such as Selective Dissemination of Information (SDI), reading assistance, and increased library orientation programs for new students. The library need to come up with programs such as, motivational talks by inviting motivational speakers to give talks to the current trends, debates or discussions on topics affecting their day to day lives. the school need to form clubs with the aim of identifying and using students talents to encourage this group of students and develop a sense of belonging to the society.

\section{Lending out some of specialised information resources}

The study recommends that the school introduces a program where the students are provided with the resource for a specific period such that when they return the resource, they are given for the next group.Non-print resources should be properly utilized by visually impaired students. DVDs can be used to project a given topic in the classes offered. Talking books will be useful for the totally blind as they enjoy listening to the audio information. These machines are simply designed only with three switches thus, on/off, volume control and track change which they can operate easily. 
The school can also make a formal request for increased funds from the GOK in order to purchase enough books and seek for permission to be exempted by Copyright Act to reproduce special-format material from original printed versions. budget allocated for Library's needs from the grant they receive from GOK. also the authority can approach the publishers, non-governmental organisation, religious groups and well-wishers for addational materials and digitization of available in print.

\section{Specialised equipment for visually impaired students}

The study recommends for additional support equipment in the library such as more Braille machine, talking books recorded, more tactile, computer for the blind, magnifying glasses and stylus, embossed Braille machine, Computers, tape recorders and sensory aids among others which are currently inadequate. magnifying glasses, slates and stylus, white canes to be compulsory for students to use while the rest could be procured.

The study further proposes networking of the Library for easy access to the internet and resources. With the advancement in ICT technologies, this would benefit the visually impaired by converting the print and access information on the web. Also adopting broadcasting media to keeping in touch with current global happenings and trends.

\section{Recruitment of staff with special skills}

The study recommends that the school request for qualified personnel with special skills to teach those students with visual impairments for theto move safely, confidently, and independently within school and the community. Further training on tough typing, computer use; low vision aids devices and sensory aids which would benefit the students.

\subsection{Conclusions}

Based on the study's findings, the following conclusions were drawn. The students undertake different activities in school. However the totally blind ones who do adopted biology; home science and agriculture do not have adequate materials for these activities, such as tactile diagram and skeletons among others. The Students do not participate in co-curriculum activities apart from athletics. It was established that not all information need were met. This has been hindering effective studies. The students get skilled in using the Braille and other devices during their studies. However they struggle searching for assistance and using communication devices which are of importance to them. The school has a Library with information materials which are informative, educational and recreational but these materials are inadequate and outdated. The students have not been trained to retrieve information and the librarian in charge does not have professional qualifications in Library Science or Special Education. There was no library program available for the students which would motivate them in different fields like politics and various club activities. The school has print resources which were inadequate and for non-print resources the only CDs encoded with information which was not current. The students cannot search information independently and especially the totally blind. They require assistance of the sighted people as they seek information.The students lack skills in computers and internet and program for leisure were not available during the time of study.

\section{References}

American Foundation for the Blind. (2013). [Online] Available at:

http://www.afb.org/section.aspx?FolderID=3\&SectionID=44\&TopicID=189\&DocumentID=2646. Accessed on 19 March 2013.

Barrington, G (2001). The Disability Discrimination Act 1995 and its implications for the provision of library services. Manual. [Online] Available at: www.nlbuk.org/bpm/cphter3.htm

Beverly, C.A and Bath, P.A (2004). Healthy information need of visually impaired student: a systematic review of literature in health care and social care.Vol 12 No.1 pp. 1-24

Bruce, I, Mckennel, A, and Walker E (2001) 'a'. Access for written information: the view of 1000 people with sighted problems. London: RNIB.

Bruce, I, Mckennel, A, and Walker E (1991) 'b”. Blind as partially sighted adults in Britain: London, RNIB survey

Catherine A, Beverly P, Rosemary B (2011). Health and social care information for visually impaired people, ASLIB Proceedings, 63(2), pp. 256-274 
Chong, C. (2002). Web accessibility: making your Web site accessible to the blind, http://204.245.133.32/tech/webacc.htm.

Choukhande V.G. (2008). Information needs and seeking behavior: library and information science research) Delhi: Shivneri.

Cole, M and Cheeseman, C. (1998). Understanding the needs of people from ethnic communities with visual impairments (draft report).

Crawford, S. (1978). Information need and uses. A manual review of information science and Technology, PP. 13, 61-81.

Creswell, J. W. (2007). Qualitative inquiry and research design: choosing among five approaches, Thousand Oaks, CA: Sage Publications.

Curry, S.A and Hatlen, P.H. (1987). Meeting the Unique Educational Needs of Visually Impaired Pupils through Appropriate Placement.

Desta, D. (1995). Needs and provisions in the area of special education: the case of Ethiopia

Davies, J. E. (2007). An overview of international research into the library and information needs of visually impaired people. Library Trends 55(4):785-796.

Deaton, H (Turner, M ed). (1993). Out of sight, out of reach, out of bounds: access to

information. For visually disabled people. London: Greater London Association of Disabled People.

Devlieger, P. (1989). Culture-based concepts and social life of disabled persons in sub-Saharan Africa: The case of the deaf. Paper presented at The Deaf Way: an International.

Disability Discrimination Act (UK, 2005). Available at http://www. www.officialdocuments.gov.uk/document/../9780108508066.pdf (Accessed 20 April 2013).

Edwards, B.J. and Lewis, S. (1998). The use of technology in programs for students with visual impairments in Florida. Journal of Visual Impairment and Blindness, May, 302-312.

Ellis, D. Cox, D. and Hall, K (1993). A comparison of the information seeking patterns of researchers in the physical and social sciences. Journal of Documentation, 49: 356-369.

Friend, C. (2009). "Meeting the Needs of the Visually Impaired Persons: What Challenges

for IP?" Paper presented at a meeting hosted by WIPO in Geneva, July 13, 2009.

[Online] Available at:

http://www.wipo.int/meetings/en/2009/vip_ge/presentations/chris_friend.html

Fullmer, S. and Majumber, R.K. (1991). Increased access and use of disability related information for consumers. Journal of Rehabilitation, 57, July-September, 17-22.

Gallimore, A. (1999). When special becomes every day. Library Technology, 4(1), 13, 16. Gargiulo, R.M. (2003). Special Education in Contemporary Society: An introduction to exceptionality. Wadsworth Learning Inc.

Hartley, J. (2006). Disabled students in higher education. British Journal of Educational Technology, 37(5), 808-809.

Hampshire, B. (1981). working with Braille: a study of Braille as a medium of communication. UNESCO.

Hanninen, K.A (1975). Teaching the visually handicapped, Columbus, Charles E.Merrill http://kidseducationkenya.org/thika-school-for-the-visually-impaired-opportunities/: http://ksblind.org/site/KSB\%20Annual\%20Report\%.pdf:Accessedon $7^{\text {th }}$ July 2012) http://www.who.int/msa/mnh/ems/icidh/brochure/whatis.htm Access on 26 July, 2012).

Heiman, T (2004). International Journal of Special Education: teachers coping with changes:

Including students with disabilities 2004, Vol 19, No.2.

IFLA (1999). The Public library manifesto. The Hague: united Nations.

Kamunge, J.K. (1988). A report on the presidential working party on education and manpower development in Kenya, Nairobi: Government Press.

Karugu, G. K. (1994). Special education trends and issues in relation to teacher education curriculum. A paper presented at the third teacher education seminar at Egerton University.

Kengrey, K. P (2002). Concept of information seeking and their presence in the practical library literature, Library Philosophy and Practice, 4(2).

Kenya gazette supplement (2002). No 48 bills no 16

Kenya Society for the Blind (2012). KSB Annual Report 2012.[Online] Available at:

http://www.ksblind.org/images/pdf/Annual\%20Reports/KSB\%20Annual\%20Report\%202012.pdf. 
Klemz A (1977). Blindness and partial sighted: care of visually impaired handicapped. Wooded: Faulkner.

Koech, K.D. (1999). Total integrated education and training, Nairobi: Government Press.

Krikelas J. (1983). Information seeking behavior: patterns and concepts. Drexel Library Quarterly, 19(2), pp.520.

Kumar, D. (2003). Science for student with visually impaired: teaching suggestions and policy implications for secondary educators.

Long, C.A. (1993). Making information available to partially sighted and blind clients. Electronic Library, pp. 373-384.

Machell, J (1996). Library and information services for visually impaired people. London: Library Association.

Malone, L., \& DeLucchi, L. (1979). Life science for visually impaired students. Science and

Children, 16(3), 29-31

Manthorp, H (1996). South Worcestershire Visual Impairment Project: Survey Report Worcestershire Association for the Blind.

Masey, H (1997). The information and support needs of newly visually impaired people. London: RNIB.

Massis, B. (ed.) (1996). Serving print disabled library patrons: a textbook for facilitators of

Library service to people with visual or physical impairments. Jefferson, N.C.: McFarland.

Meeting the needs of the handicapped: a resource centre for teachers and librarians (1980) London: Oryx Press.

Moore, N. (2003) "a". The information needs of visually impaired people: A review of research. London: RNIB.

Moore, N. (2002) "b". A model of social information need. Journal of information science, vol.28 no 4, pp. 297303.

Morris, D. (1978). Man watching. A field to human behaviors. London: Panther

Mugenda and Mugenda (1999). Research methods: qualitative and quantitative. Nairobi: ACT Press.

Muya, E.W. (1990). Development of library services for visually handicapped: a basic strategy'. Proceeding of Kenya library association annual seminar $27^{\text {th }}$ feb-2 march (unpublished).

Nicholas J. (2006). Libraries digitization and disability, Library Review, 55(3), pp. 168-172

Ochoggia, R.E. (2003). 'Provision of library information services to visually handicapped students in Kenya public university.

Oso W.Y. and Onen D. (2005). A general guide to writing searches proposal \& report: A handbook for beginning researchers. Nairobi: Option Printers and Publishers.

Payne, P (1990). Sampling techniques and recruiting respondent in research methods in Library and information studies/ed. by Margaret slate. London, the Library Association.

Person with disabilities bill (2002). Nairobi: Government printers.

inion, C. (1990. Audio services for the blind and partially sighted in public libraries.

Audiovisual Librarian, 16 (1) 24-28.

Pirolli, P. and Card, S.K. (1999). Information foraging, Psychological Review, 106, pp.643-75.

Porter, P. (1997). The reading washing machine. Vine, 106, 34-37.

Raymond E. O (2003). Persons with Disabilities bills 2002: implications concerning Visual disabilities for academic libraries and information services in Kenya, New Library World, 104(7), pp 307-312.

Royal National Institute for the Blind (2001). Accessible Web design available at:

http://www.rnib.org.uk/digital/hints.htm.

Royal National Institute for the Blind (2001) "a". The main UK organization representing the

needs and interests of blind and visually impaired people. Provides a wide range of information and advice, and lobbies on behalf of the community it represents: Available at: http://www.rnib.org.uk/.

RNIB (2010)"b". Access to Information - Reports. Available at: http://www.rnib.org.uk/campaigning-policy-andreports-hub-access-information/access-information-reports.

RNIB (1998)"c". Informed: Royal institute for the blind. London: Campaign report 7.

Roth, H. (1991). Planning information services in the disability field: some essential steps, Link-Up 66, February.

Royal National Institute for the Blind (1999). How RNIB can help. URL: http://www.mib.org.uk/services/welcome.htm Accessed Dec 201999.

Saunders, M. (2007). Research methods for business students. $-4^{\text {th }}$ ed. - London: Pearson Education Limited.

Savolainen, R. (1995). Everyday life information seeking: approaching information seeking in the context of way of life, Library and Information Science Research, 17, pp.259-94. 
Sekaran, U. (2006). Research methods for business: a skill building approach. $-4^{\text {th }}$ ed. - New Delhi: John Wiley and Sons.

Singh J (2009). Library and information science in digital age: essays in honour of Prof. M.P. Satija. New Delhi: Ess Publications.

Slater, M. (ed.). (1990). Research methods in library \& information. London: The Library Association.

Sorenson L. S. (1999). Accessible library services: taking action to enhance services for persons with disabilities. Illinois: Skokie public Library.

UN General Assembly (1994) a/res/44/96 Standard rules on the equalization of opportunity for person with disabilities. Available at:

www.un.org/documentation/ga/res/48r096.htm.

UNESCO (1985). A Guide to teacher training programmes in special education in Africa: Ensco Sub-Regional Project for Special Education in Eastern and Southern Africa. Nairobi, Kenya.

Velleman, R.A. (1990). Meeting the needs of people with disability: a guide for librarians, educator, and serve professionals. Phoenix, AZ: Oryx Press,.

Verweyen, P. (2004). Low Vision Services Provided by the Low Vision Project-Kenya. Available at: http://icevi.org/publications/icevix/wshops/0262.html.

Wagner, B. V. (1995). Measurement for students who are visually impaired. In: Egelston-

Dodd, J. (Ed.). Improving Science Instruction for Students with Disabilities: Proceedings of

a Working Conference on Science for Persons with Disabilities. IA: University of Northern Iowa, 7.

Waihenya, K. (2000, May 22). 8-4-4 locks out disabled children. East African Standard.

Walsh J. (2006). Improving web accessibility for visually impaired, Library Hi Tech News, 23 (8), pp. 29-31.

Warner, E. S., Murray, J. and Palmour, V. E. (1973). Information Needs of Urban Residents.

Final report from the Regional Planning Council of Baltimore and Westat Inc. of

Rockville, MD to the U.S. Department of Health.

Willetts, G (1997). Services for people with visual impairments in Lotion - a review report for the social services department. London: RNIB.

Williamson K, Schauder D and Bow, A (2000). Information seeking by blind and sight impaired citizens: an ecological study, Information Research, 5(4). Available at: http://informationr.net/ir/5-4/paper79.html.

Wilson, T.D (1999). Models in information behaviour research, Journal of Documentation, 34(1), pp. 63-73.

Winnie, V (1994). Managing national library for Blind and print handicapped persons, Library Management, 15(7), pp. 23-28.

Wohler's, H. D. (1994). Science education for students with disabilities. In Egelston-Dodd, J.

(ed). A future agenda: Proceedings of a working conference on science for persons with disabilities. IA: University of Northern Iowa, pp. 52-64.

World Health Organization (1999). Beginner's guide to ICIDH-2.

Yamane, T. (1967). Statistics: An Introductory Analysis, 2nd ed. New York: Harper and Row. 